\title{
Maimonides (1135-1204) and his philosophy of medicine
}

\author{
Peter M Dunn
}

Moses Maimonides was born in Cordova, the capital of Moorish Spain, on 30 March 1135. His father, Maimon, was a judge of the Jewish religious courts. Until the family fled to $\mathrm{Fez}$ in 1159 , because of religious persecution, Maimonides was a pupil of the philosopherphysician Averroes (1126-98). From Morocco the family moved on to Palestine and then to Egypt. Shortly after arriving in Cairo, his father died and his brother David, a dealer in precious stones, was drowned in the Indian Ocean, leaving a widow and young daughter. Maimonides wrote: "... how should I console myself? He grew up on my knees and he was my brother, he was my pupil; and he traded in the market and earned, and I could sit safely at home." Now he had to practise medicine to support both families. His learning and wisdom were already widely acknowledged and in 1170 he was appointed physician to the Court of Saladin. He also became Rayyis (Head) of the Jewish community. He was 36 years old.

Life was not easy. Maimonides described a typical day's work as follows: "My duties to the Sultan are very heavy. I am obliged to visit him every day, early in the morning; and when he or any of his children, or any of the inmates of his harem, are indisposed I dare not leave Cairo, but must spend the greater part of the day in the palace.... I repair to Cairo very early in the day, and even if nothing unusual happens, I do not return to Fostat until the afternoon. Then I am fatigued and hungry. I find the antechambers filled with people ... I converse with and prescribe for them while lying down from sheer fatigue, and when night falls I am so exhausted that I can scarcely speak.”

Maimonides would have much preferred to continue the contemplative life of a sage, a rabbi, and a philosopher (fig 1). He was deeply versed in the classical writings of Hippocrates, Aristotle, and Galen and in the rabbinic teachings of the Bible and the Talmud. $^{2} \mathrm{He}$ recognised that science had not achieved certain knowledge of nature and wrote: "The dangers are obvious to the wise while the fools do not find anything difficult ... Behold: inasmuch as a man be perfect in this wisdom, new doubts arise in him which lead to added contemplation." He attributed the causes of errors to : "(1) Love of contradiction and opposition which hinders people from conceiving a thing as it is in reality; (2) profundity of

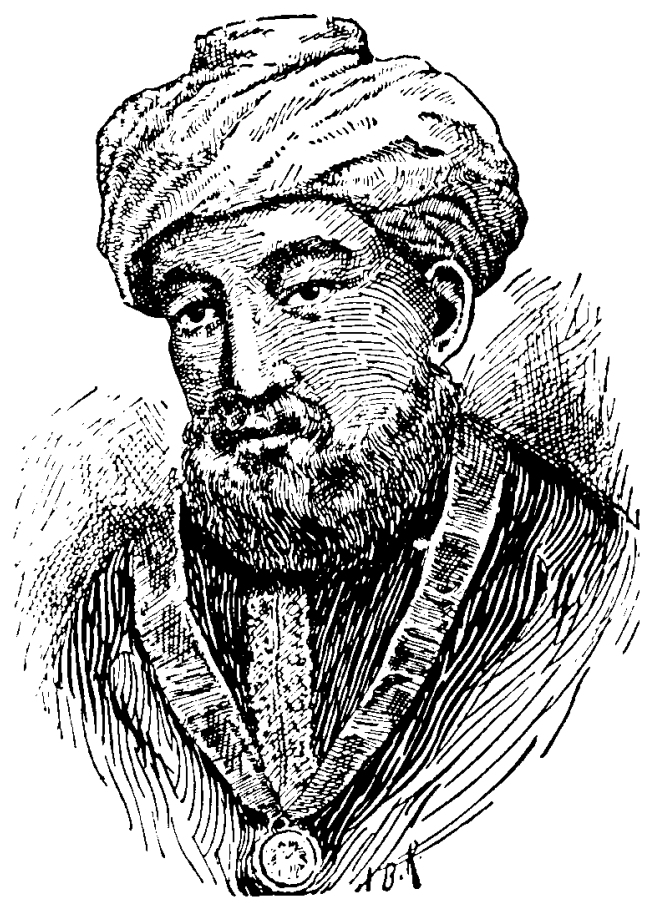

Figure 1 Moses Maimonides (AD 1135-1204).

the thing to be conceived, its subtlety, its power, and the difficulty to conceive it; (3) foolishness of the conceiver and his disability to apprehend what is quite within the powers of conception; (4) and the fourth cause is routinism, since people adhere by nature to their habits, incline to them and detest any other opinion, even if it be nearer to the truth."

Maimonides advocated a very broad education for doctors and emphasised the need to maintain physical health and vigour, for, as he wrote: “... it is impossible for one to understand sciences and meditate upon them when he is hungry or sick." $\mathrm{He}$ enumerated rules for maintaining health, telling those who obeyed them that: "I give him a guaranty that ... he will not need a physician, and his body will be perfect and faultless all his days. This on the condition that his body was not imperfect from birth, that he has not adopted bad conduct from childhood, and that there did not come a disaster of plague or dryness upon the world."

He was fully aware of the importance of psychosomatic disorders and warned against hurrying to treat such cases with medicine. He 
wrote: “Therefore it is the physicians' order to keep in sight the movements of the soul, to study them constantly, and to try to bring them into balance in health as well as in disease ... It is the first principle in the treatment of every patient, and especially in psychic diseases ...”

His advice to the surgeons was also very sound: "When you think of cutting out something of the body, keep in mind three intentions. The first, that your work shall be finished in the shortest time possible; the second, that no pain at all shall be caused; the third, that you be sure of the result. However, the result will require three intentions. First, be clearly aware that your intentions will be attained with certainty; second, if this cannot be achieved, at least no damage shall ensue from side effects; third, be sure that the disease shall not relapse. Then when you consider these intentions it will be evident to you that at times surgical and at times medicinal treatment will be more praiseworthy."

Maimonides bemoaned the fact that "people ... seek medical help from anyone whom they meet by chance and from everything which seems new." He elaborated on the dangers of seeking advice from too many physicians: “... seldom is a physician called to treat a patient from the beginning of his illness till its end; rather they wander from one physician to another. Sometimes the patient is being attended by ten physicians according to his means, without one knowing of the other. The patient then takes the advice of each of the doctors, makes his decision, and chooses what he finds good by his own judgment. This practice has disadvantages ... First, the perplexity of the patient himself who does not know with whom the truth lies. Second, the perplexity of the physician; because, if he could attend the case from beginning to end, then seeing success he would continue his way of treatment, while seeing the contrary he would take another way. Third, the damage to the physicians when every one of them criticises his fellow physician and imputes errors to him. And fourth, the inertness of the physician and the weakness of his thought, and his dependence on the others; and his knowing that if he erred the error will not be attached to his name alone; and if he were on the right way, he would not be the only one to be credited with the success. Therefore he will not strive to proceed as he should according to his opinion, knowing that nobody relies on him alone." Maimonides recognised too how difficult it was for a doctor "to make money and at the same time to practice the immense art (of medicine); of necessity he will despise the one, the more eagerly he hastens towards the other."

Besides codifying, commentating, and translating many of the great classic authors, Maimonides made many original observations of his own, including works on the anatomy of the uterus and on sexual intercourse. But it was on medical ethics that he made his greatest contribution. For example, when conflict arose between the life of a woman and her fetus, he taught that the life of the mother should take precedence and that, if necessary, an embryotomy should be performed. This advice, in contrast to the teaching of the Christian church, became accepted Jewish practice.

Maimonides' ethical guidance to physicians is encapsulated in this famous prayer:

"O God, let my mind be ever clear and enlightened. By the bedside of the patient let no alien thought deflect it. Let everything that experience and scholarship have taught it be present in it and hinder it not in its tranquil work. For great and noble are those scientific judgements that serve the purpose of preserving the health and lives of Thy creatures.

Keep far from me the delusion that I can accomplish all things. Give me the strength, the will, and the opportunity to amplify my knowledge more and more. Today I can disclose things in my knowledge which yesterday I would not yet have dreamt of, for the Art is great, but the human mind presses on untiringly.

In the patient let me ever see only the man. Thou, All Bountiful One, has chosen me to watch over the life and death of Thy creatures. I prepare myself now for my calling. Stand Thou by me in this great task, so that it may prosper. For without Thine aid man prospers not even in the smallest things."

Maimonides died in Cairo on 13 December 1204 , at the age of 69 . He was buried in Tiberias in Palestine. With his death, his reputation as philosopher, rabbi, and physician assumed even higher respect in Arabic and Christian as well as in Jewish circles. In spite of this the Council of Vienna in AD 1267 forbade Jews in future to practise among Christians.

1 Leibowitz J O. Maimonides on medical practice. Bull Hist Med 1957;31:309-17.

2 Leiber E. Galen: physician as philosopher. Maimonides: philosopher as physician. Bull Hist Med 1979;53:268-85. 